\title{
VANDALISME DALAM KEGIATAN WISATA HUTAN DI TAMAN KUPU-KUPU GITA PERSADA BANDAR LAMPUNG
}

\section{(VANDALISM ON FOREST TOURISM ACTIVITIES IN THE GITA PERSADA BUTTERFLY PARK BANDAR LAMPUNG)}

\author{
Anggih Pararinarno ${ }^{1)}$, Agus Setiawan ${ }^{2)}$, dan Jani Master ${ }^{3)}$ \\ ${ }^{1)}$ Mahasiswa Jurusan Kehutanan Fakultas Pertanian Universitas Lampung \\ ${ }^{2)}$ Dosen Jurusan Kehutanan Fakultas Pertanian Universitas Lampung \\ ${ }^{3)}$ Dosen Jurusan Biologi Fakultas Matematika dan Ilmu Pengetahuan Alam Universitas Lampung \\ Jl. Soemantri Brojonegoro No. 1 Bandar Lampung \\ Email : anggihpararinarno@gmail.com \\ Phone : 085669365982
}

\begin{abstract}
ABSTRAK
Taman Kupu-Kupu Gita Persada adalah salah satu bentuk model wisata hutan yang lokasinya berdekatan dengan daerah perkotaan. Wisata jenis ini memiliki daya tarik yang tinggi, sehingga menimbulkan minat bagi wisatawan untuk mengunjunginya. Wisatawan yang berkunjung ke taman ini diduga akan menimbulkan dampak negatif, antara lain vandalisme. Tujuan penelitian ini adalah mengidentifikasi bentuk-bentuk vandalisme pada pohon dan kelompok umur wisatawan yang melakukan vandalisme, serta mengetahui persepsi wisatawan terhadap vandalisme. Penelitian ini dilaksanakan pada bulan Januari-Februari 2015 dengan menggunakan metode pengamatan dan wawancara. Persentase individu tumbuhan yang terkena vandalisme pada lokasi yang digunakan sebagai wisata sebesar $8,91 \%$. Persentase individu tumbuhan yang terkena vandalisme pada lokasi yang tidak digunakan sebagai kegiatan wisata $10,91 \%$. Secara umum, pengunjung memiliki persepsi bahwa kegiatan vandalisme ini merusak pohon dan keindahan tempat wisata serta diperlukan tindakan pencegahan oleh pengelola Taman Kupu-Kupu Gita Persada terhadap kegiatan vandalisme.
\end{abstract}

Kata Kunci : wisata hutan, vandalisme, taman kupu-kupu gita persada

\section{ABSTRACT}

The Gita Persada Butterfly Park is one of the examples of a region that can be selected as an object of forest tourism which is located near city areas. This kind of tourism has own interest, so make enthusiasts of the travellers to visit this forest tourism. The travellers who visiting this park were assumed would create the negative impacts such as vandalism. The goals of this research are to identify the forms of the tree's vandalism and the group of ages from the travellers who did the vandalism, and than knowing the perceptions of the travellers against the vandalism. This research was done in January-February 2015 by using an observation method and interview. The plant's percentage that suffered vandalism at the location that used as a tourism activity is 8,91\%. The plant's percentage that suffered vandalism at the location that not used as a tourism activity is 10,91\%. Generally, the visitors have perceptions these vandalism activities damage trees and the beauty of the tourism object as well as they are needed the prevention acts by the orginizer of Gita Persada Butterfly Park about vandalism activities.

Key words : forest tourism, vandalism, gita persada butterfly park 


\section{PENDAHULUAN}

Hutan memiliki keunikan tersendiri dari segi lansekap maupun segi keanekaragaman hayati. Pemanfaatan hutan selain sebagai sistem pendukung kehidupan, salah satunya adalah sebagai wahana wisata hutan. Menurut Bharuna (2009), wisata alam merupakan salah satu bentuk wisata alternatif. Kualitas kawasan atau objek wisata hutan adalah unsur penentu dalam memikat daya tarik wisatawan untuk mengunjungi lokasi wisata hutan. Secara umum, pada dasarnya ada dua aspek dalam pemanfaatan wisata yaitu melindungi sumber daya dan kualitas pengalaman berwisata (Sayan dan Atik, 2011).

Hal yang tidak kalah penting dalam menjaga keanekaragaman satwa liar adalah menjaga lingkungan alami tempat hidupnya (Rahayu dan Basukriadi, 2012). Indonesia adalah negara nomor satu dalam sumber alam hayati kupu-kupu dan Lampung memiliki 60\% spesies kupu-kupu yang terdapat di Indonesia, oleh karena itu Taman Kupu-Kupu Gita Persada harus memenuhi syarat habitat yang baik bagi kupu-kupu agar jumlah spesies kupu-kupu tidak mengalami kepunahan (Handayani, Sugiyanta, dan Zulkarnain, 2012).

Daya dukung berkaitan dengan jumlah dan tipe pemanfaatan yang dapat diterima oleh kawasan dan areal terkait tanpa mengakibatkan dampak negatif terhadap kawasan dan kualitas berwisata (Manning, 2001). Hal ini sejalan dengan pengertian ekowisata yaitu suatu bentuk wisata yang bertanggung jawab terhadap kelestarian areal yang masih alami (natural area), memberi manfaat secara ekonomi, dan mempertahankan keutuhan budaya masyarakat setempat (Maulida, Anggoro, dan Susilowati, 2012). Waluya (2013) menjelaskan, perkembangan pariwisata yang sangat pesat dan terkonsentrasi dapat menimbulkan berbagai dampak. Adanya dampak negatif dari wisata alam terhadap kawasan, diperlukan pengelolaan dan perencanaan yang sesuai untuk meminimalisir dampak yang ditimbulkan (Purnomo, Sulistryantara, dan Gunawan, 2013). Bagaimana dampak yang dapat ditimbulkan oleh wisatawan terhadap kegiatan wisata?. Sehubungan dengan hal tersebut, maka mengidentifikasi dampak kegiatan wisata berupa vandalisme sangat diperlukan untuk mengurangi dampak kerusakan akibat dari aktivitas wisatawan.

Tujuan penelitian adalah mengidentifikasi bentuk-bentuk vandalisme pada pohon sebagai dampak kegiatan wisata hutan dan kelompok umur wisatawan yang melakukan vandalisme serta mengetahui persepsi wisatawan terhadap vandalisme. Hasil penelitian ini diharapkan dapat menambah informasi dan menjadi bahan masukan bagi pengelola Taman Kupu-Kupu Gita Persada maupun pihak terkait lainnya dalam upaya mencegah vandalisme.

\section{METODE PENELITIAN}

\section{Lokasi dan Waktu Penelitian}

Penelitian ini dilaksanakan pada bulan Januari - Februari 2015 meliputi tahap persiapan, pengambilan data dan dilanjutkan dengan pengolahan dan analisis data. Areal pengamatan ditetapkan dengan cara memilih dua lokasi di dalam Taman Kupu-Kupu Gita Persada yang kondisinya berbeda. Lokasi pertama merupakan areal yang digunakan sebagai tempat kegiatan wisata sedangkan lokasi kedua merupakan areal yang tidak digunakan kegiatan wisata.

Populasi penelitian adalah pengunjung Taman Kupu-Kupu Gita Persada. Berdasarkan informasi pengelola taman kupu-kupu, jumlah pengunjung taman kupu-kupu adalah 125 wisatawan perbulan. Jumlah responden yang diwawancarai dihitung menggunakan rumus Slovin (Arikunto, 2010), yaitu sebagai berikut : 


$$
\begin{aligned}
& n=\frac{N}{N \mathrm{e}^{2}+1} \\
& n=\frac{125}{1250,1^{2}+1} \\
& n=\frac{125}{1,25+1} \\
& n=\frac{125}{2,25}=55,56 \Rightarrow 56 \text { responden }
\end{aligned}
$$

Keterangan:

$n$ : Jumlah resonden

$\mathrm{N}$ : Jumlah populasi

e : presisi $10 \%$

1 : bilangan konstant

Sehingga jumlah responden pada penelitian ini adalah 56 responden.

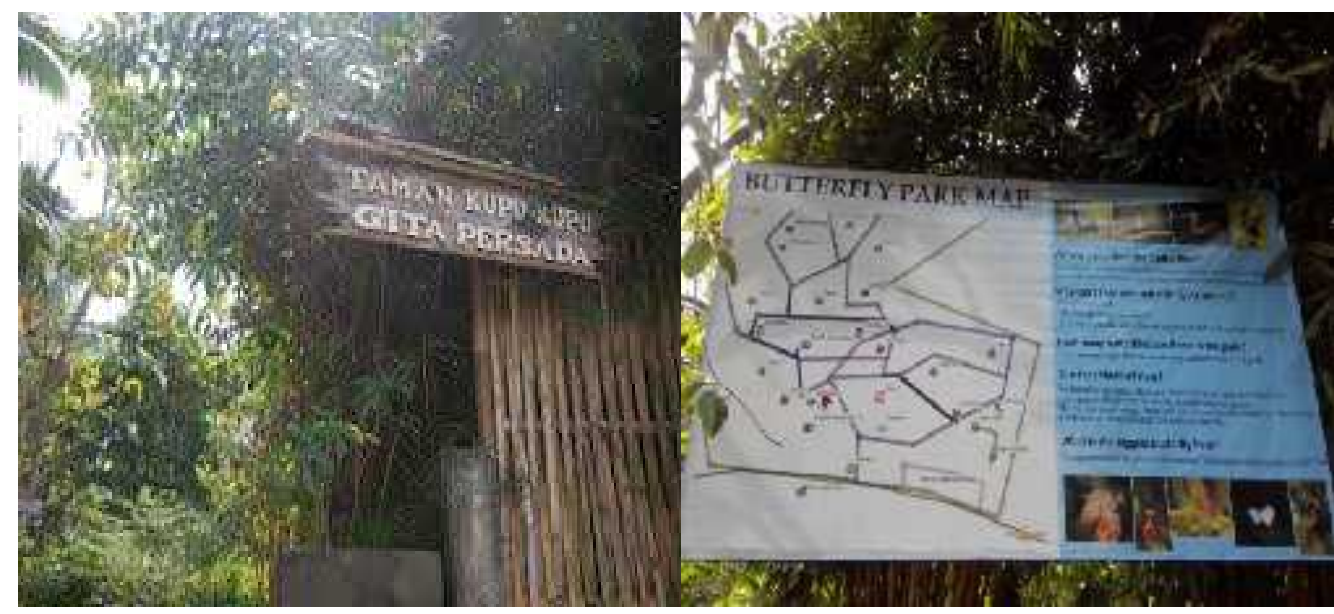

Gambar 1. Taman Kupu-Kupu Gita Persada.

\section{Alat dan Bahan}

Objek yang diamati pada penelitian ini adalah pohon dan wisatawan/pengunjung di kawasan Taman Kupu-Kupu Gita Persada. Alat yang digunakan dalam penelitian ini adalah rol meter, kamera, tally sheet, kuisioner, alat tulis, Phiband, dan komputer/laptop.

\section{Metode Analisis Data}

Data yang telah terkumpul dianalisis menggunakan metode, antara lain:

a. Variabel bentuk-bentuk vandalisme pada pohon dianalisis dengan metode deskriptif kuantitatif.

b. Persentase individu tumbuhan terkena vandalisme dihitung menggunakan rumus:

$$
\text { Persentase vandalisme }=\frac{\text { jumlah individu terkena vandalisme }}{\text { jumlah keseluruhan individu }} \times 100 \%
$$

c. Variabel frekuensi bentuk-bentuk vandalisme pada pohon dihitung menggunakan rumus:

$$
\mathrm{F}=\frac{\text { jumlah ditemukannya suatu bentuk vandalisme jenis ke }-i}{\text { jumlah seluruh bentuk vandalisme pada pohon }} \times 100 \%
$$


d. Rata-rata vandalisme pada tiap individu dihitung menggunakan rumus:

Rata-rata vandalisme $=\frac{\text { Jumlah vandalisme }}{\text { jumlah keseluruhan individu }}$

e. Variabel karakteristik wisatawan dan persepsi wisatawan dianalisis secara deskriptif kuantitatif.

\section{HASIL DAN PEMBAHASAN}

\section{Kerusakan Akibat Vandalisme}

Pada lokasi yang digunakan sebagai kegiatan wisata ditemukan 101 individu tumbuhan terdiri atas 36 jenis, 59 tumbuhan fase tiang dan 42 tumbuhan fase pohon. Rambutan (Nephelium lappaceum) memiliki jumlah terbanyak yaitu 10 individu. Jenis dengan diameter terbesar yaitu kemiri (Aleurites moluccana) yaitu $60 \mathrm{~cm}$ sedangkan jati (Tectona grandis) dan merbau (Intsia palembanica) adalah jenis dengan diameter terkecil yaitu $11 \mathrm{~cm}$.

Pada lokasi yang tidak digunakan sebagai kegiatan wisata ditemukan 55 individu tumbuhan yang terdiri dari 8 jenis. Terdapat 12 tumbuhan fase tiang dan 43 tumbuhan fase pohon. Sonokeling (Dalbergia latifolia) memiliki jumlah terbanyak yaitu 34 individu. Tumbuhan dengan diameter terbesar yaitu sonokeling $(77 \mathrm{~cm})$ dan tumbuhan dengan diameter terkecil yaitu durian (Durio zibethinus) yang memiliki diameter $12 \mathrm{~cm}$. Hasil pengamatan disajikan pada Tabel 1.

Bentuk vandalisme yang terdapat di lokasi yang digunakan kegiatan wisata adalah goresan dengan frekuensi $100 \%$, pada lokasi ini bentuk vandalisme berupa coretan atau bacokan tidak ditemukan. Pada lokasi ini bentuk vandalisme keseluruhannya adalah goresan dengan jumlah sebanyak 18 goresan. Sedangkan vandalisme yang ditemukan di lokasi tidak digunakan wisata berjumlah 14 yang terdiri atas 8 bacokan dan 6 goresan (Tabel 2). Frekuensi bentuk vandalisme bacokan yang ditemukan sebesar $57 \%$ sedangkan frekuensi bentuk vandalisme goresan yang ditemukan pada lokasi ini sebesar $43 \%$.

Persentase individu tumbuhan yang terkena vandalisme pada lokasi yang digunakan sebagai kegiatan wisata sebesar $8,91 \%$. Sedangkan persentase pada lokasi yang tidak digunakan sebagai kegiatan wisata $10,91 \%$. Rata-rata vandalisme pada lokasi yang digunakan sebagai kegiatan wisata didapat nilai sebesar 0,18 . Nilai rata-rata vandalisme pada lokasi yang digunakan sebagai kegiatan wisata merupakan nilai rata-rata vandalisme berupa goresan. Sedangkan lokasi yang tidak digunakan sebagai kegiatan wisata diperoleh nilai sebesar 0,25 diantaranya rata-rata vandalisme berupa bacokan sebesar 0,14 dan rata-rata vandalisme berupa goresan sebesar 0,11. Berdasarkan nilai yang diperoleh ini, lokasi yang tidak digunakan sebagai kegiatan wisata memiliki nilai vandalisme yang lebih besar dibandingkan dengan lokasi yang digunakan sebagai kegiatan wisata. Pada lokasi yang tidak digunakan wisata ini merupakan areal yang jarang dikunjungi oleh pengunjung, akan tetapi memiliki nilai vandalisme yang lebih besar dibandingkan dengan areal lainnya. Menurut Utaminingtyas, Astiningsih, dan Mayun (2012) menyatakan bahwa faktor lingkungan yang mempengaruhi pelaku vandalisme adalah lokasi yang relatif sedikit pengunjung.

Bentuk vandalisme berupa coretan tidak ditemukan baik pada lokasi yang digunakan sebagai kegiatan wisata maupun lokasi yang tidak digunakan sebagai kegiatan wisata. Vandalisme yang ditemukan lebih banyak pada lokasi yang digunakan sebagai kegiatan wisata. Bentuk vandalisme berupa bacokan hanya ditemukan pada lokasi yang tidak digunakan sebagai kegiatan wisata. Bentuk vandalisme berupa goresan ditemukan pada kedua lokasi dan goresan lebih banyak ditemukan pada lokasi yang digunakan sebagai kegiatan wisata. 
Tabel 1. Daftar jenis tumbuhan pada lokasi kegiatan wisata di Taman Kupu-Kupu Gita Persada.

\begin{tabular}{|c|c|c|c|c|}
\hline \multirow[t]{2}{*}{ No } & \multicolumn{2}{|c|}{ Nama Jenis } & \multicolumn{2}{|c|}{$\begin{array}{c}\text { Jumlah Individu Tumbuhan Pada } \\
\text { Areal }\end{array}$} \\
\hline & Nama Lokal & Nama Ilmiah & $\begin{array}{l}\text { Digunakan } \\
\text { Wisata }\end{array}$ & $\begin{array}{c}\text { Tidak Digunakan } \\
\text { Wisata }\end{array}$ \\
\hline 1 & Biola & Ficus pandurata & 2 & - \\
\hline 2 & Durian & Durio zibethinus & 9 & 11 \\
\hline 3 & Ketapang & Terminalia catappa & 2 & - \\
\hline 4 & Medang & Dehaasia caesia & 6 & - \\
\hline 5 & Kemiri & Aleurites moluccana & 7 & - \\
\hline 6 & Weru & Albizia procera & 4 & - \\
\hline 7 & Cengal & Hopea sangal & 4 & - \\
\hline 8 & Waru & Hibiscus tiliaceus & 2 & 5 \\
\hline 9 & Pulai & Alstonia scholaris & 3 & - \\
\hline 10 & Rambutan & Nephelium lappaceum & 10 & 1 \\
\hline 11 & Petai & Parkia speciosa & 3 & - \\
\hline 12 & Nangka & Artocarpus heterophyllus & 4 & - \\
\hline 13 & Sonokeling & Dalbergia latifolia & 2 & 34 \\
\hline 14 & Sengon laut & Paraserianthes falcataria & 2 & - \\
\hline 15 & Angsana & Pterocarpus indicus & 2 & - \\
\hline 16 & Melinjo & Gnetum gnemon & 1 & - \\
\hline 17 & Tabu & Tetrameles nudiflora & 1 & - \\
\hline 18 & Salam & Syzygium polyanthum & 2 & - \\
\hline 19 & Jati & Tectona grandis & 6 & - \\
\hline 20 & Mangga & Mangifera indica & 3 & - \\
\hline 21 & Kapuk & Ceiba pentandra & 1 & - \\
\hline 22 & Saga & Adenanthera pavonina & 1 & - \\
\hline 23 & Merbau & Intsia palembanica & 2 & - \\
\hline 24 & Mahoni & Swietenia macrophylla & 4 & - \\
\hline 25 & Bungur & Lagerstroemia speciosa & 1 & - \\
\hline 26 & Palem & Wodyetia bifurcata & 3 & - \\
\hline 27 & Tembesu & Fragraea fragrans & 1 & - \\
\hline 28 & Alpukat & Persea americana & 2 & - \\
\hline 29 & Jambu batu & Psidium guajava & 2 & - \\
\hline 30 & Duku & Lansium domesticum & 1 & - \\
\hline 31 & Kayu manis & Cinamomum zeylanicum & 1 & 1 \\
\hline 32 & Sawo & Manilkara kauki & 1 & - \\
\hline 33 & Bayur & Pterospermum javanicum & 1 & - \\
\hline 34 & Lamtorogung & Leucaena leucocephala & 1 & - \\
\hline 35 & Buni & Antidesma bunius & 1 & - \\
\hline 36 & Matoa & Pometia pinnata & 3 & - \\
\hline 37 & Cengkeh & Syzygium aromaticum & - & 1 \\
\hline 38 & Kakao & Theobroma cacao & - & 1 \\
\hline 39 & Jambu air & Syzygium aquеum & - & 1 \\
\hline & & nlah & 101 & 55 \\
\hline
\end{tabular}

Tabel 2. Bentuk vandalisme yang ditemukan pada Taman Kupu-Kupu Gita Persada.

\begin{tabular}{|c|c|c|}
\hline \multirow{2}{*}{ Bentuk Vandalisme } & \multicolumn{2}{|c|}{ Jumlah Pada Lokasi (Areal) } \\
\hline & Digunakan Wisata & Tidak Digunakan Wisata \\
\hline Coretan & - & - \\
\hline Goresan & 18 & 6 \\
\hline Bacokan & - & 8 \\
\hline Jumlah & 18 & 14 \\
\hline
\end{tabular}




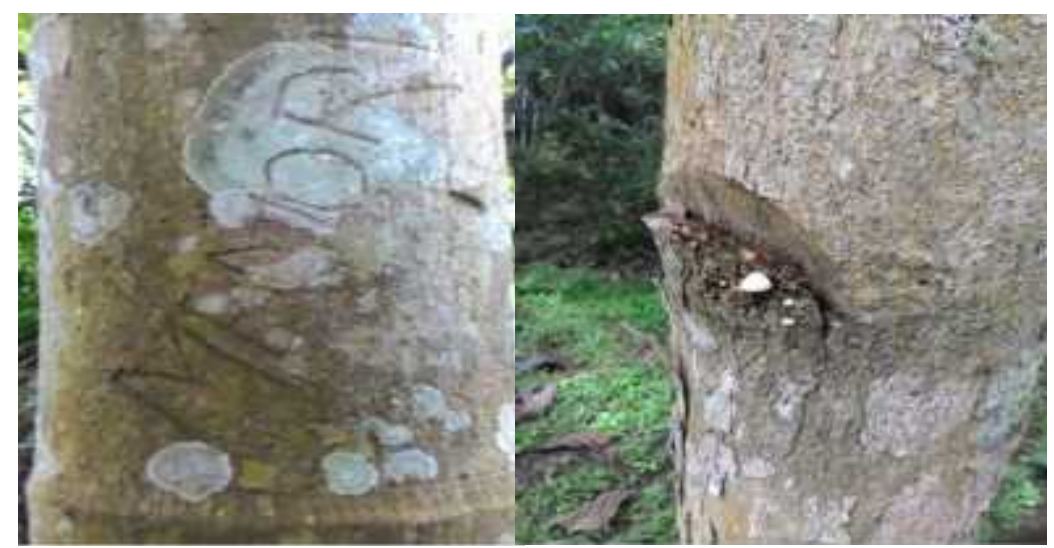

Gambar 2. Bentuk vandalisme berupa goresan/ukiran dan bacokan.

Menurut Mulyana (2013), secara individu bahwa setiap jenis pohon mempunyai karakteristik dan fungsi yang berbeda seperti dalam hal estetika. Oleh karena itu, vandalisme tidak hanya mengurangi peran dari pohon tetapi juga mengurangi nilai estetika terlebih untuk kawasan wisata. Faktor lingkungan yang mempengaruhi pelaku melakukan aktivitas vandalisme pada objek pohon yaitu berada dalam jangkauan tangan dan memiliki keindahan atau keunikan (Utaminingtyas et al., 2012).

\section{Karakteristik/Profil Wisatawan}

Data karakteristik wisatawan diperoleh untuk mengetahui karakteristik/profil dari wisatawan itu sendiri. Data karakteristik/profil wisatawan diperoleh dengan cara wawancara terhadap wisatawan yang mengunjungi Taman Kupu-Kupu Gita Persada berdasarkan kelompok umur yang telah ditentukan sebanyak 56 responden. Menurut Departemen Kesehatan Republik Indonesia (2009), kategori umur dibagi ke dalam kelompok yaitu:
1. Balita
: 0 - 5 tahun
2. Kanak-kanak : 5-11 tahun
3. Remaja : :12-25 tahun
4. Dewasa : $26-45$ tahun
5. Lansia : :46-65 tahun
6. Manula : 65 tahun ke atas

Pengunjung yang diwawancari mengaku pernah melakukan kegiatan vandalisme di tempat wisata sebanyak 8 pengunjung. Sedangkan 48 pengunjung lainnya mengaku tidak pernah melakukan kegiatan vandalisme di tempat wisata. Pengunjung yang mengaku pernah melakukan vandalisme sangat sedikit jumlahnya dibandingkan dengan pengunjung yang mengaku tidak pernah melakukannya, tidak jarang pengunjung sungkan untuk mengakuinya.

Pengunjung yang diwawancarai berada pada kelompok umur yang berbeda (Gambar 3). Pengunjung yang mengakui pernah melakukan kegiatan vandalisme di tempat wisata memiliki kisaran umur antara 12-45 tahun atau pada kategori umur remaja dan dewasa. Pengunjung yang mengaku pernah melakukan kegiatan vandalisme sebanyak 7 orang yang berada pada kelompok umur remaja. Sedangkan 1 orang yang mengaku pernah melakukan kegiatan vandalisme berada pada kelompok umur dewasa. 


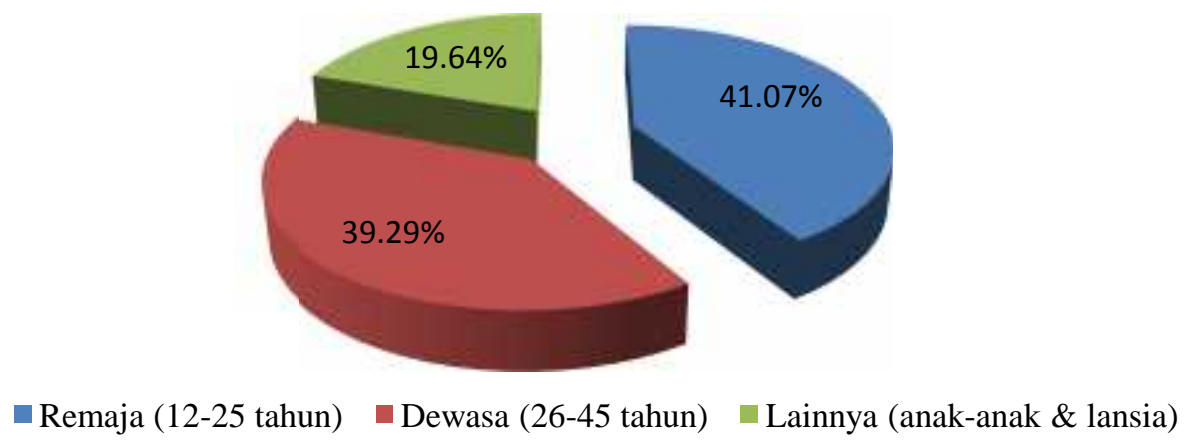

Gambar 3. Umur pengunjung yang dijumpai di Taman Kupu-Kupu Gita Persada.

Berdasarkan tingkat pendidikan pengunjung yang pernah melakukan vandalisme di tempat wisata adalah tingkat SMP/sederajat sebanyak 2 orang (25\%), tingkat SMA/sederajat 3 orang $(37,5 \%)$, dan 3 orang $(37,5 \%)$ dengan latar belakang pendidikan Perguruan Tinggi (Gambar 4). Wisatawan yang berkunjung ke Taman Kupu-Kupu Gita Persada berasal dari berbagai daerah, akan tetapi sebagian besar $(67,86 \%)$ berasal dari Kota Bandar Lampung. Pengunjung yang mengakui pernah melakukan kegiatan vandalisme seluruhnya berasal dari Kota Bandar Lampung.

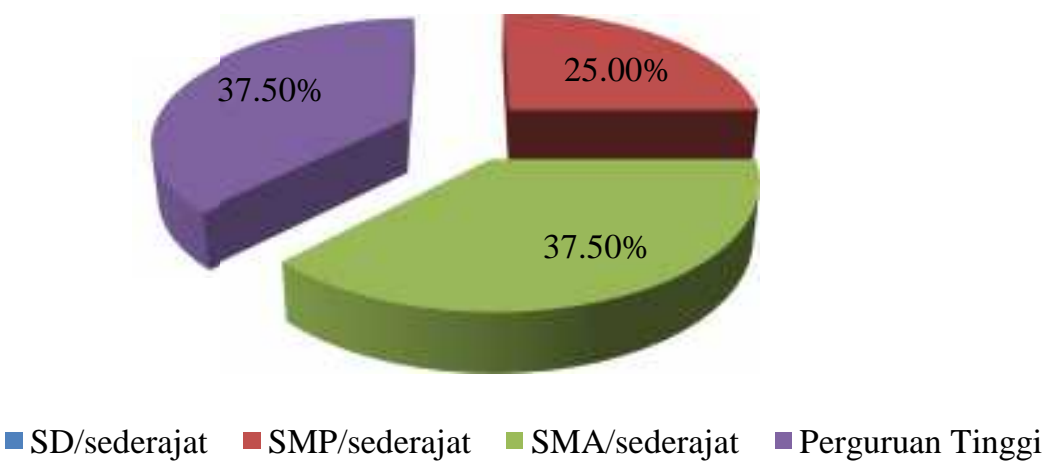

Gambar 4. Pendidikan pengunjung yang dijumpai di Taman Kupu-Kupu Gita Persada.

Sebagian besar pengunjung Taman Kupu-Kupu Gita Persada merupakan remaja yang berasal dari Kota Bandar Lampung sehingga pengunjung yang melakukan vandalisme didominasi oleh kelompok umur remaja. Walaupun pengunjung memiliki tingkat pendidikan yang cukup tinggi akan tetapi sangat sedikit dari pengunjung yang mengetahui bahwa vandalisme dapat mengurangi estetika. Sehingga dapat menimbulkan niat pengunjung untuk melakukan vandalisme.

Namun bila dihubungkan kebiasaan melakukan vandalisme atau gangguan terhadap objek/aset wisata alam yang lain, kelompok umur wisatawan yang potensial untuk melakukan gangguan terhadap objek adalah wisatawan yang berada pada kelompok umur 11-20 tahun. Hal ini tentu saja tidak berarti bahwa kelompok umur ini adalah pelaku sebenarnya dari kegiatan perusakan. Akan tetapi kewaspadaan terhadap wisatawan pada kelompok umur ini memang perlu diakomodasi dalam bentuk manajemen pengunjung/wisatawan secara proposional, didorong oleh pengalaman empiris bahwa kelompok umur ini merupakan kelompok remaja yang masih labil kondisi kejiwaannya, sehingga sering mencoba mengaktualisasikan dirinya melalui cara yang tidak konservatif, misalnya vandalisme (Fandeli, Utami, Kaharudin, Susilowati, dan Wijaya, 2004). 


\section{Persepsi Wisatawan}

Hasil wawancara menunjukkan bahwa sebagian besar $(89,3 \%)$ pengunjung mengaku tidak mengetahui arti vandalisme, hanya 6 pengunjung (10,7\%) mengetahui arti vandalisme. Kelompok umur pengunjung yang mengetahui arti vandalisme sebanyak 5 orang remaja dan 1 orang dewasa serta seluruhnya memiliki latar belakang pendidikan tingkat Perguruan Tinggi. Hal yang tidak jauh berbeda juga ditunjukkan pada persepsi pengunjung tentang bentukbentuk vandalisme pada pohon. Persepsi pengunjung yang mengetahui bentuk-bentuk vandalisme pada pohon sangat sedikit, sebagian besar $(92,86 \%)$ tidak mengetahui. Pengetahuan pengunjung mengenai vandalisme sangat kurang, pengunjung lebih banyak tidak mengerti dan tidak memahami vandalisme. Hal ini disebabkan pengunjung tidak mengenal lebih jauh mengenai vandalisme.

Sebagian besar pengunjung $(82,14 \%)$ mengetahui bahwa kegiatan vandalisme tidak hanya merusak pohon bahkan keindahan dari tempat wisata itu sendiri. Hanya 17,86 \% pengunjung yang tidak mengetahui bahwa kegiatan vandalisme dapat merusak pohon dan keindahan tempat wisata. Menurut Simanjuntak (2012) menyatakan bahwa dari persepsi responden terdiri dari berbagai jenis kelamin dan latar belakang pekerjaan, dapat diidentifikasi bahwa bentuk tindakan vandalisme adalah merusak karena mayoritas responden umumnya mengatakan bahwa sebagai tindakan yang merusak.

Pengunjung berpendapat bahwa diperlukan tindakan terhadap kegiatan vandalisme oleh pihak pengelola untuk pencegahan dan penanganan terhadap kegiatan vandalisme, terutama yang dilakukan oleh wisatawan yang berkunjung ke Taman Kupu-Kupu Gita Persada (Gambar 5). Bentuk upaya pencegahan dan penanganan terhadap kegiatan vandalisme dapat berupa sosialisasi terhadap wisatawan serta adanya himbauan, pemberitahuan, atau larangan melakukan vandalisme yang dapat ditempatkan di sekitar taman.

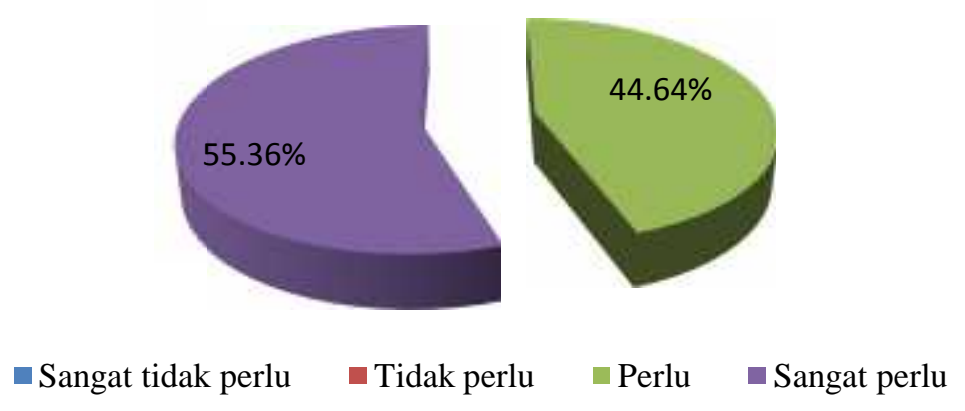

Gambar 5. Persepsi pengunjung tentang tindak lanjut dari pengelola Taman Kupu-Kupu Gita Persada untuk menangani kegiatan vandalisme.

\section{KESIMPULAN}

Berdasarkan penelitian yang telah dilakukan di Taman Kupu-Kupu Gita Persada, maka diperoleh kesimpulan sebagai berikut:

1. Bentuk vandalisme pada pohon yang ditemui di Taman Kupu-Kupu Gita Persada adalah goresan dan bacokan serta tidak ditemukan bentuk vandalisme berupa coretan.

2. Responden yang mengaku pernah melakukan kegiatan vandalisme di tempat wisata selain Taman Kupu-Kupu Gita Persada adalah kelompok umur remaja dan dewasa dengan jumlah keseluruhan sebanyak 8 responden. 
3. Secara umum pengunjung memiliki persepsi bahwa kegiatan vandalisme ini merusak pohon dan keindahan tempat wisata serta diperlukan tindakan pencegahan dan penanganan oleh pengelola Taman Kupu-Kupu Gita Persada terkait kegiatan vandalisme.

\section{DAFTAR PUSTAKA}

Arikunto, S. 2010. Prosedur Penelitian: Suatu Pendekatan Praktik. Buku. Rineka Cipta. Jakarta. 413 hal.

Bharuna, A.A.G.D. 2009. Pola perencanaan dan strategi pembangunan wisata alam berkelanjutan serta berwawasan lingkungan. Jurnal Bumi Lestari. 9(1):121-128.

Departemen Kesehatan RI. 2009. Profil Kesehatan Indonesia. Buku. Jakarta. Departemen Republik Indonesia. 165 hal.

Fandeli, C., R. N. Utami, Kaharudin, S. Susilowati, dan Wijaya. 2004. Identifikasi dampak kegiatan wisata alam terhadap komponen biotis di kawasan Wisata Alam Tlogo Putri Kaliurang. Laporan Akhir. Universitas Gadjah Mada. Yogyakarta. 46 hal.

Handayani, V.D., I. G. Sugiyanta, dan Zulkarnain. 2012. Deskripsi habitat kupu-kupu di Taman Kири-Kupu Gita Persada Kelurahan Kedaung Kecamatan Kemiling Kota Bandar Lampung tahun 2012. Jurnal Penelitian Geografi. Vol 1(2).

Manning, R.E. 2001. Programs that work visitor experience and resource protection: $a$ framework for managing carrying capacity of national parks. Journal of Park and Recreation Administration. 19(1):93-108.

Maulida, H.F., S. Anggoro, dan I. Susilowati. 2012. Pengelolaan wisata alam air panas cangar di Kota Batu. Jurnal Ekosains. IV (3).

Mulyana, S. 2013. Kajian jenis pohon potensial untuk hutan kota di Bandung, Jawa Barat. Jurnal Analisis Kebijakan Kehutanan. 10(1):58-71.

Purnomo, H., B. Sulistryantara, dan A. Gunawan. 2013. Peluang usaha ekowisata di kawasan Cagar Alam Pulau Sempu Jawa Timur. Jurnal Penelitian Sosial dan Ekonomi Kehutanan. 10(4):247-263.

Rahayu, S.E. dan A. Basukriadi. 2012. Kelimpahan dan keanekaragaman spesies kupu-kupu (Lepidoptera; rhopalocera) pada berbagai tipe habitat di Hutan Kota Muhammad Sabki Kota Jambi. Jurnal Biospecies. 5(2): 40-48.

Utaminingtyas, A., A. A. M. Astiningsih, dan I. A. Mayun. 2012. Studi hubungan vandalisme dengan setting Taman Lapangan Puputan Badung I Gusti Ngurah Made Agung Denpasar - Bali. E-Jurnal Agroekoteknologi Tropika. 1(2).

Sayan, M. S. and M. Atik. 2011. Recreation carrying capacity estimates for protected areas: a study of Termessos National Park (Turkey). Jurnal Ekoloji. 20(78):66-74.

Simanjuntak, N. 2012. Kemunculan vandalisme dan seni graffiti di ruang bawah jalan layang. Skripsi. Universitas Indonesia. Depok. 64 hal.

Waluya, J. 2013. Dampak pengembangan pariwisata. Jurnal Region. 5(1). 
Vol. 3 No. 3, September 2015 (1-10)

Halaman ini sengaja dikosongkan 